\title{
The significance of metamorphic fluorite in the Adirondacks*
}

\author{
S. R. BoHlen and E. J. ESSENE \\ The Department of Geology and Mineralogy, The University of Michigan, Ann Arbor, \\ MI 48109 , U.S.A.
}

(Received 20 January 1978; accepted in revised form 5 July 1978)

\begin{abstract}
Thermodynamic calculations for selected silicate-oxide-fluorite assemblages indicate that several commonly occurring fluorite-bearing assemblages are restricted to relatively narrow $f_{\mathrm{O}}-f_{\mathrm{F}_{2}}$ fields at constant $P-T$. The presence of fayalite-ferrohedenbergite-fluorite-quartz \pm magnetite and ferrosalite-fluorite-quartz-magnetite assemblages in orthogneisses from Au Sable Forks, Wanakena and Lake Pleasant, New York, buffered fluorine and oxygen fugacities during the granulite facies metamorphism in the Adirondack Highlands. These buffering assemblages restrict $f_{\mathrm{F}_{2}}$ to $10^{-29 \pm 1}$ bar and $f_{0_{2}}$ to $10^{-10 \pm 1}$ bar at the estimated metamorphic temperature of $1000 \mathrm{~K}$ and pressure of $7 \mathrm{kbar}$. The assemblage biotite-magnetite-ilmenite-K-feldspar, found in the same Au Sable Forks outcrop as the fayalite-fluorite ferrohedenbergite-quartz-magnetitie assemblage, restricts $\mathrm{H}_{2} \mathrm{O}$ fugacities to less than $10^{3.3}$ bar. These fugacities limit $\mathrm{H}_{2}$ and $\mathrm{HF}$ fugacities to less than $10^{1}$ bar for the Au Sable outcrop. The data indicate that relative to $\mathrm{H}_{2} \mathrm{O}, \mathrm{O}_{2}, \mathrm{H}_{2}, \mathrm{~F}_{2}$ and $\mathrm{HF}$ are not major species in the fluid equilibrated with Adirondack orthogneisses. The calculated $F_{2}$ fugacities are similar to the upper limits possible for plagioclase-bearing rocks and probably represent the upper $f_{\mathrm{F}}$ limit for metamorphism in the Adirondacks and in other granulite facies terranes.
\end{abstract}

\section{INTRODUCTION}

OF THE three most common fluoride minerals known in terrestrial igneous and metamorphic rocks [fluorite $\left(\mathrm{CaF}_{2}\right)$, villiaumite $(\mathrm{NaF})$ and cryolite $\left.\left(\mathrm{Na}_{3} \mathrm{AlF}_{6}\right)\right]$, fluorite is the most abundant (STORMtR and CARMICHAEL, 1970). Fluorite is a typical accessory phase in hypersolvus granites, fayalite granites, syenites and nepheline syenites. It is also a common mineral in skarns and hydrothermal veins. Villiaumite and cryolite are best known as rare accessory phases in quartzsaturated and undersaturated rocks, although cryolite occurs in minable quantities at Ivigtut. Greenland. Because of the rarity of these sodium fluorides, one must turn to fluorite reactions and hence reactions involving Ca-silicates in order to evaluate $f_{\mathrm{F}_{2}}$ and $f_{\mathrm{HF}}$ in many igneous and metamorphic rocks.

Despite the frequent occurrence of fluorite as an accessory phase, there are little experimental data on fluorite stability or the relative stability of other fluoride minerals. Stormer and CARMiChaEL (1970) calculated the relative stabilities of villiaumite. cryolite and fluorite coexisting with acmite-plagioclasemagnetite \pm nepheline \pm quartz as a function of $f_{\mathrm{O}_{2}}-f_{\mathrm{F}_{2}}-T$. MUNOZ and EUGSTER (1969) investigated three fluorine-oxygen buffering reactions involving wollastonite-fluorite-quartz, anorthite-fluoritesillimanite-quartz and calcite-fluorite-graphite. Using these buffers Munoz and Eugster established experimentally that phlogopites efficiently scavenge fluorine from the fluid phase. They concluded that the pres-

* Contribution No. 0344 from the Mineralogical Laboratory, The Department of Geology and Mineralogy, The University of Michigan, Ann Arbor. MI 48109. U.S.A. ence of $\mathrm{HF}$ in the fluid phase can profoundly affect mica compositions even though $\mathrm{HF}$ concentration in equilibrium with the three buffers studied is extremely low.

The Munoz-Eugster (1969) and the StormerCARMichaEl (1970) studies estimate fluorite stabilities in a few assemblages. However, the stability of fluorite in equilibrium with iron-rich ortho- and clinopyroxenes, fayalite, quartz and iron oxides has not yet been carefully evaluated. Reactions among the minerals in these fluorite-bearing assemblages buffer $f_{\mathrm{O}_{2}}$ and $f_{\mathrm{F}_{2}}$, and the presence of these assemblages in Adirondack metamorphics allow a calculation of $f_{\mathrm{O}_{2}}-f_{\mathrm{F}_{2}}$ fugacities in a few orthogneisses. These data coupled with estimates of $f_{\mathrm{H}_{2} \mathrm{O}}$ allow restriction of values for $f_{\mathrm{H}_{2}}$ and $f_{\mathrm{HF}}$. We have considered $\mathrm{F}_{2}$ and $\mathrm{O}_{2}$ as variables rather than $\mathrm{HF}$ and $\mathrm{H}_{2} \mathrm{O}$ because $f_{\mathrm{F}}$, and $f_{\mathrm{O}}$, directly control the reactions of interest; this eliminates the need for accurate knowledge of $f_{\mathrm{H}_{2} \mathrm{O}}$ and $f_{\mathrm{H}_{2}}$ in calculations of mineral stabilitics using $f_{\mathrm{HF}}$ and $f_{\mathrm{H}_{2} \mathrm{O}}$ as variables. Use of $f_{\mathrm{F}_{2}}$ and $f_{\mathrm{O}_{2}}$ is to be preferred in application to any rocks where $f_{\mathrm{H}, \mathrm{O}}$ is uncertain, i.e. most igneous and many metamorphic rocks. Evaluation of gas fugacities is necessary to understand more fully the composition and rolc of fluids during the Grenville granulite facies metamorphism in the Adirondack Highlands.

\section{ADIRONDACK FLUORITE ASSEMBLAGES}

Fluorite is a widespread accessory phase in skarns and gneisses in the Adirondack Highlands. LEONARD and BudDington (1964) describe fluorite in a number of magnetite-rich gneisses and skarns in the NW 
Adirondacks. Assemblages include:

ferrosalite-scapolite - microcline - sphene - fluorite \pm calcite \pm andradite

biotite-sphene-fluorite \pm magnetite \pm sulfides biotite-quartz-K-feldspar-magnetite \pm spessartine \pm fluorite

biotite-quartz-K-feldspar-sillimanite-fluorite (tr)plagioclase (ti).

These assemblages do not buffer $f_{\mathrm{F}_{2}}$ and $f_{\mathrm{O}_{2}}$ by simple reactions except for the last which carries both products and reactants of the reaction

\section{2 anorthite (ss. in plag.) $+2 \mathrm{~F}_{2}$}

$=2$ fluorite +2 sillimanite +2 quartz $+\mathrm{O}_{2}$.

If these phases are in equilibrium and the composition of the plagioclase is determined, the univariant curve can be calculated in $f_{\mathrm{F}_{2}}-\mathrm{f}_{\mathrm{O}_{2}}$ space at constant $P-T$. BUDDINGTON and LEONARD (1962) report fluorite in alaskites near South Russell, Fine, Parishville and Oswegatchie in the NW Adirondacks. Typical mineral assemblages are quartz-microcline-plagioclase-amphibole-fluorite \pm sphene \pm zircon \pm biotite \pm iron oxides. They also report the assemblage quartz-microperthite-plagioclase-ferrohedenbergitefayalite-hornblende-ilmenite-zircon-fluorite in fayalite granites near Wanakena, New York. At this locality fluorite occurs in association with fayalite-ferrohedenbergite-amphibole clots (see Fig. 1), and it is nearly always juxtaposed to these other mafic minerals. KEMP and Alling (1925) have reported fluorite-bearing assemblages in the Au Sable Quadrangle. Fluorite occurs in a fayalite granite near $\mathrm{Au}$ Sable Forks and in a granite on Palmer Hill, north of Au Sable Forks. In addition to these localities investigated by the writers, a new fluorite occurrence was also discovered near Lake Pleasant. Fine-grained fluorite $(25 \mu \mathrm{m})$ occurs in a quartz mangerite together with clinopyroxene $\left(\mathrm{Hd}_{70}\right)$, orthopyroxene $\left(\mathrm{Fs}_{82}\right)$, quart $z$, microcline perthite $\left(A b_{30}\right)$, plagioclase $\left(A n_{23}\right)$ and magnetite $\left(U v_{2.1}\right)$. The occurrence of such small grains of primary fluorite in a typical Adirondack orthogneiss is significant; fluorite might be a more common primary phase than reported. Careful microscopic examination of nearly 200 thin sections of charnockite and mangerite has failed to reveal additional fluorite-bearing assemblages. However, small grains $(<25 \mu \mathrm{m})$ could easily go undetected despite extensive searching, especially in a partially altered rock.

The fluorite-bearing assemblages in the Adirondacks may have buffered oxygen and fluorine fugacities. The buffering reactions are:

$$
\begin{aligned}
3 \text { hedenbergite }+3 \mathrm{~F}_{2}= & 3 \text { fluorite }+1 \text { magnetite } \\
& +6 \text { quartz }+\mathrm{O}_{2}
\end{aligned}
$$

* The cell volume of synthetic hedenbergite $\left(450.04 \AA^{3}\right)$ reported by KURCHAKOVA and AVETISYAN (1974) disagrees with their cell dimensions and should read $450.44 \AA^{3}$ which converts to $67.83 \mathrm{~cm}^{3} / \mathrm{mol}$ and is in good agreement with the volume $\left(67.88 \mathrm{~cm}^{3} / \mathrm{mol}\right)$ of LINDSLEY et al. (1968).
2 hedenbergite $+2 \mathrm{~F}_{2}=2$ fluorite +1 fayalite

$$
+3 \text { quartz }+\mathrm{O}_{2}
$$

1 hedenbergite +1 magnetite $+\mathrm{F}_{2}$

$$
=1 \text { fluorite }+2 \text { fayalite }+\mathrm{O}_{2} \text {. }
$$

A knowledge of pressures and temperatures of metamorphism will allow calculation of oxygen and fluorine fugacities if experimental calibration of these reactions or the Gibbs free energy of the solid phases is a vailable.

\section{ANALYTICAL METHODS}

Most of the free energy data for thermodynamic calculations were taken from JANAF $(1971,1974.1975)$ tables and RoBiE and WaLDBaUM (1968) with adjustments as given in HEMINGWAY and RoBIE (1977) and CODATA (1976). The $\Delta G_{T}^{0}$ data for $\mathrm{FeF}_{2}$ were obtained from SchafFer (1975). Free energy data for hedenbergite and andradite were calculated from experimental curves of Liou (1974). The free energy obtained for hedenbergite $(-554,151 \mathrm{cal} / \mathrm{mol})$ agrees well with estimates of NAVROTSKY and COONS (1976) at $1350 \mathrm{~K}$. When estimates of hedenbergite entropy are made $\left(S_{T}^{0} \mathrm{Hd} \simeq S_{T}^{0} \mathrm{Di}+\right.$ $1 / 2 S_{T}^{0} \mathrm{Fa}-1 / 2 S_{T}^{0} \mathrm{Fo}$ ), one may calculate $\Delta G_{1000}^{0}$ $\mathrm{Hd}=-553.160 \mathrm{cal} / \mathrm{mol}$ from their $\Delta G_{1350}^{0}$ estimate. KURCHAKOVA and AVETISYAN (1974) also estimated the free energy for hedenbergite, obtaining $\Delta G_{1000}^{0} \mathrm{Hd}=-550.504$ $\mathrm{cal} / \mathrm{mol}$ a fortuitously good agreement in view of their reliance on unreversed experimental data not in agreement with Liou's reversals. The free energy for sphene was calculated from HUNT and KERRICK's (1977) experiments. Table 1 contains the $\Delta G_{1000}^{0}$ data used in construction of Figs. 2 and 3. Molar volumes of the minerals were obtained from RoBIE and WALDBaUM (1968) and CLARK for $V^{0}$ (Hd) which was taken from LindsLeY et al. (1968).* The $V^{o}$ of $\mathrm{FeF}_{2}, \mathrm{TiF}_{4}$ and $\mathrm{ZrF}_{4}$ were calculated from reported densities, and the $V^{0}$ for $\mathrm{K}_{3} \mathrm{AlF}_{6}$ was calculated from ASTM cell volume data. The $f_{O_{2}} f_{1_{2}}$ phase diagram was calculated using the equation

$$
\Delta G(P, T)=\Delta G_{T}^{0}+\frac{\wedge V_{s} \wedge P}{41.84}+R T \ln f_{\mathrm{O}_{z}}^{n} f_{\mathrm{F}_{2}}^{m}
$$

where $n$ and $m$ are the numerical coefficients for $\mathrm{O}_{2}$ and $\mathrm{F}_{2}$ respectively in a given equation with $n$ moles of $\mathrm{O}_{2}$ on the right-hand side and $m$ moles of $F_{2}$ on the left. The assumption that $\Delta V_{s}(P . T) \simeq \Delta V_{s}(1 \mathrm{~atm} . .298 \mathrm{~K})$ produces negligible errors for these calculations. Figure 2 has been constructed at constant $P$ of $7 \mathrm{kbar}$ and $T$ of $1000 \mathrm{~K}$. the estimated conditions in the Adirondacks (BOHLFN and ESSENE. 1977a). For comparison we have calculated the $\mathrm{F}_{2}-\mathrm{O}_{2}$ buffers used by MUNOZ and EligSTER (1969) as well as some other simple reactions in Figs. 2 and 3. BURT (1972) schematically constructed a diagram similar to $\mathrm{Fig} .2$ in the system $\mathrm{CaO}-\mathrm{FeO}-\mathrm{SiO}_{2}-\mathrm{O}_{2}-\mathrm{F}_{2}$ plotting $\mu_{\mathrm{F}_{2} \mathrm{O}_{-1}}$ vs $\mu_{\mathrm{O}_{2}}$. We consider the variable $\mathrm{F}_{2} \mathrm{O}_{-1}$ to be an unnecessary artifice. and Burt gives no magnitude or specific values for his variables. Nevertheless, the hedenbergite- and andradite-bearing reactions in Figs. 2 and 3 are topologically consistent with Burt's diagram

The location of the An-Fl-Si-Q (AFSQ) curve relative to the Wo-Fl-Q (WFQ) curve has been a matter of some dispute. MUNOZ and LCDINGTON (1974) concluded that the AFSQ buffer was incorrectly located relative to WFQ by MUNOZ and Eugster (1969). Munoz and Ludington recalculated the two curves using ROBIE and WALDBaLm's (1968) data and still inferred a discrepancy with their experimental data. They considered that errors were to be found in the free energy of the alumino-silicates and adjusted the AFSQ curve to be consistent with their experiments. The more recent thermochemical data (Table 1) 


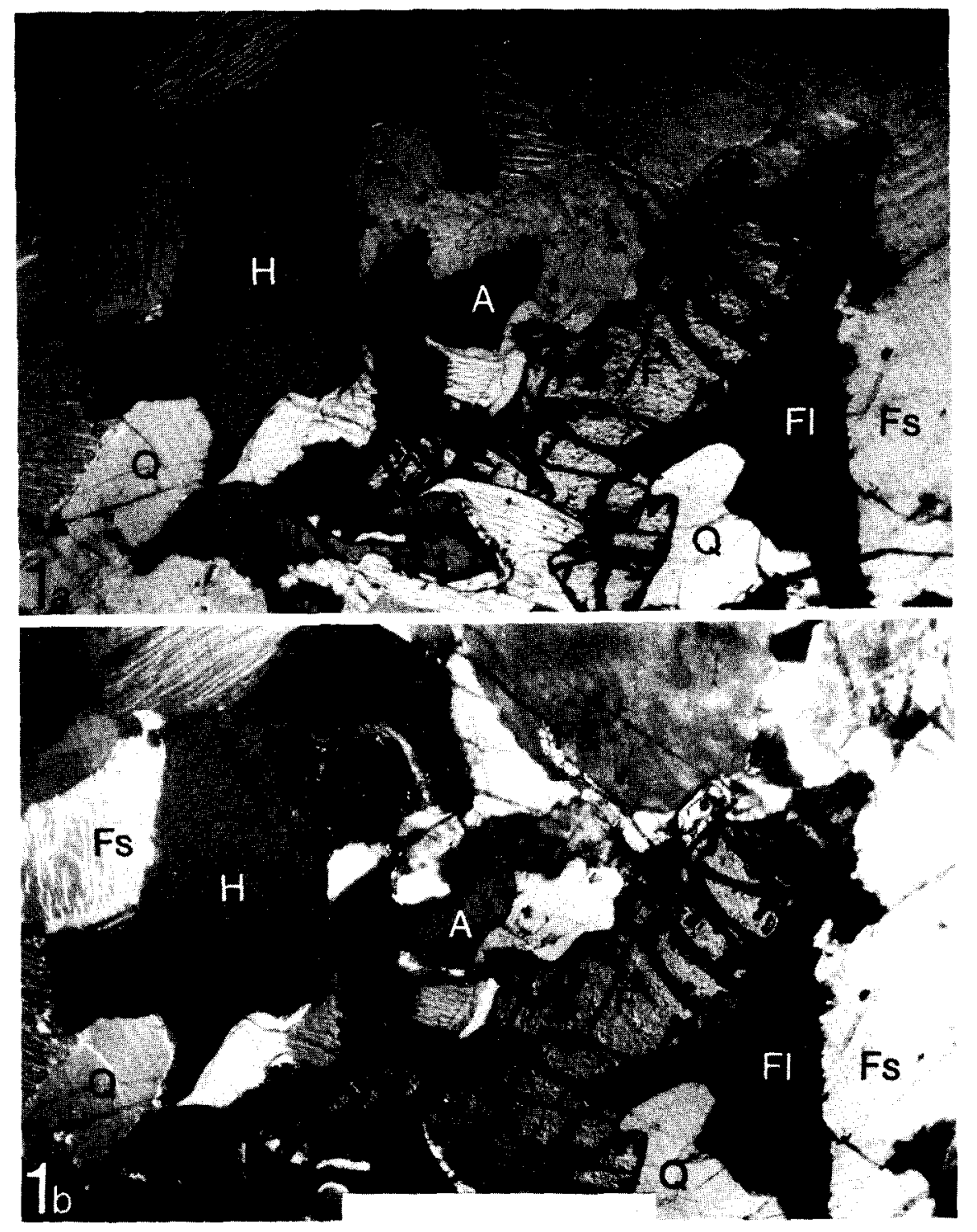

Fig. 1a. Clot of fayalite (F), ferrohedenbergite $(H)$, ferrofluoredenite (A), fluorite (stained) (FI), quartz $(Q)$, and alkali feldspar ( $F s)$ in fayalite granite near Wanakena, New York.

Fig. 1b. Same view under crossed polars. Bar scale is $0.5 \mathrm{~mm}$. 
Table 1. Free energy and volume data used for calculation of Figs. 2 and 3

\begin{tabular}{|c|c|c|c|c|c|c|}
\hline Phase & Formula & Abbrev. & $\Delta G^{0}{ }_{1000^{\circ} \mathrm{K}}$ & Reference & $V^{0} 298^{\circ} \mathrm{K}$ & Reference \\
\hline Albite, high & $\mathrm{NaAlSi}_{3} \mathrm{O}_{8}$ & $A b$ & -763408 & (8) & 100.43 & $(10)$ \\
\hline Andradite & $\mathrm{Ca}_{3} \mathrm{Fe}_{2} \mathrm{Si}_{3} \mathrm{O}_{12}$ & $\mathrm{Ad}$ & -1117638 & $(6)$ & 131.65 & $(10)$ \\
\hline Anorthite & $\mathrm{CaAl}_{2} \mathrm{Si}_{2} \mathrm{O}_{8}$ & $\mathrm{An}$ & -833596 & (8) & 100.79 & $(10)$ \\
\hline Calcite & $\mathrm{CaCO}_{3}$ & $\mathrm{Cc}$ & -227411 & (9) & 36.93 & $(10)$ \\
\hline Cryolite & $\mathrm{Na}_{3} \mathrm{AlF}_{6}$ & Cry & -659283 & (1) & 70.81 & $(10)$ \\
\hline Fayalite & $\mathrm{Fe}_{2} \mathrm{SiO}_{4}$ & $\mathrm{Fa}$ & -275030 & (8) & 46.39 & $(10)$ \\
\hline Fluorite & $\mathrm{CaF}_{2}$ & F1 & -252638 & (7) & 24.54 & $(10)$ \\
\hline HF, ideal gas & $H F$ & $\mathrm{HF}$ & $-\quad 66723$ & (7) & 0 & - \\
\hline $\mathrm{H}_{2} \mathrm{O}$, ideal gas & $\mathrm{H}_{2} \mathrm{O}$ & $\mathrm{H}_{2} \mathrm{O}$ & -46040 & (1) & 0 & - \\
\hline Hedenbergite & $\mathrm{CaFeSi}_{2} \mathrm{O}_{6}$ & Hd & -554151 & (6) & 67.88 & (11) \\
\hline Hematite & $\mathrm{Fe}_{2} \mathrm{O}_{3}$ & $H$ & -134363 & (1) & 30.27 & $(10)$ \\
\hline Ilmen i te & Fetio & I l II & -234400 & (3) & 37.69 & (10) \\
\hline Iron Fluaride & $\mathrm{FeF}_{2}$ & IF & -138112 & (4) & 22.92 & $(12)$ \\
\hline K-cryolite & $\mathrm{K}_{3} A \cap F_{\varepsilon}$ & Kcry & - 664818 & (1) & 92.14 & $(13)$ \\
\hline Lime & $\mathrm{CaO}$ & $\operatorname{Lm}$ & -126942 & (2) & 16.76 & $(10)$ \\
\hline Magnetite & $\mathrm{Fe}_{3} \mathrm{O}_{4}$ & $M$ & -189541 & (1) & 44.52 & $(10)$ \\
\hline Periclase & $\mathrm{MgO}$ & $\mathrm{Pe}$ & -117886 & $(7)$ & 11.25 & $(10)$ \\
\hline Quartz & $\mathrm{SiO}_{2}$ & Q & -174526 & (7) & 22.69 & $(10)$ \\
\hline Rutile & $\mathrm{TiO}_{2}$ & $\mathrm{Ru}$ & -182303 & (2) & 18.82 & $(10)$ \\
\hline Sanidine & $\mathrm{KAISi}_{3} \mathrm{O}_{8}$ & Or & -770290 & $(8)$ & 109.05 & $(10)$ \\
\hline Sellaite & $\mathrm{MgF}_{2}$ & $\mathrm{Se}$ & -227066 & (1) & 19.67 & $(10\rangle$ \\
\hline Sillimani te & $\mathrm{Al}_{2} \mathrm{SiO}_{5}$ & $\mathrm{Si}$ & -501057 & (1) & 49.90 & $(10)$ \\
\hline Sphene & CaTiSiO $0_{5}$ & Sph & -508885 & (5) & 55.65 & $(10)$ \\
\hline Titanium Fluoride & $T j F_{L}$ & TF & -326378 & (1) & 44.28 & $(12)$ \\
\hline Wollastonite & $\mathrm{CaSiO}_{3}$ & Wo & -323707 & (8) & 39.93 & $(10)$ \\
\hline Wustite & $\mathrm{Fe} .947^{0}$ & $W$ & $-\quad 47686$ & (1) & 12.04 & $(10)$ \\
\hline Zircon & $\mathrm{ZrSiO}_{4}$ & $2 c$ & -392935 & (1) & 39.26 & $(10)$ \\
\hline Zirconium Fluoride & $\mathrm{ZrF}_{4}$ & ZF & -378237 & (1) & 37.75 & (12) \\
\hline
\end{tabular}

References: (1) JANAF (1972); (2) JANAF (1975); (3) RoBIE and WALDBaUM (1968); (4) SCHAEFER (1975); (5) calc. from HuNT and KeRRICK (1977); (6) calc. from Liou (1974): (7) CODATA (1976); (8) Hemingway and Robie (1977); (9) Stavely and Linford (1969): (10) RoBIE et al. (1967); (11) LINDSLEY et al. (1968); (12) calc. from density; (13) calc. from ASTM cell dimensions.

have substantially different $\Delta G_{T}^{0}$ values than RoBIE and WaLDBaum (1968) for anorthite, sillimanite and fluorite. The inferred $f_{\mathrm{F}_{2}}$ for the two curves at $f_{\mathrm{O}_{2}}$ fixed by $\mathrm{NNO}$ $\left(-\log f_{\mathrm{O}_{2}}=15.68\right)$ at $1000 \mathrm{~K}$ are listed in Table 2. The WFQ curve has shifted by $-0.6 \log f_{\mathrm{F}}$, units relative to that obtained from Robie and Waldbaum's data largely because of a $-3 \mathrm{kcal} / \mathrm{mol}$ change in $\Delta G_{T}^{0}$ for fluorite. This value for fluorite has been confirmed by recent solubility, EMF and calorimetric measurements summarized in NORDSTROM and JENNE (1977). MUNOZ and Ludington's (1974) experiments imply a $1.9 \log f_{F_{2}}$ difference between AFSQ and WFQ curves. close to the value (2.1) calculated for this paper. Considering the errors, it is concluded that the writers' calculated curves are consistent with Munoz and Ludington's experiments but require a small shift to lower $f_{F_{2}}$ and $f_{\mathrm{HF}}$ in both curves from their calculated values.

Quantitative electron microprobe analyses of the Adirondack minerals were obtained in order to adjust the calculated phase equilibria for solid solutions. Major and minor element analyses were obtained using an ARL-EMX electron microprobe analyzer with wavelength dispersive PET, LiF and TAP crystal spectrometers. Spectrometer data were corrected for atomic number, fluorescence. absorption, continuous background and machine drift effects using the FORTRAN program EMPADR VII written by RUCKLIDGE and GASPARRINI (1969). Details of microprobe techniques are described in BOHLEN and ESSENE (1977a). For fluorite analyses the electron beam was spread out to approx $25-30 \mu \mathrm{m}$ and the beam energy reduced to $10 \mathrm{keV}$ in order to minimize volatilization. Thousand second energy dispersive analyses failed to reveal any elements besides $\mathrm{Ca}$, although care was taken to look for rare earth elements. The writers conclude that the fluorite in Adirondack orthogneisses is $>99.5 \%$ pure $\mathrm{CaF}_{2}$. For all minerals ferric iron has been inferred by normalization about the cations with adjustment of ferrous-ferric ratio to maintain stoichiometry. For pyroxenes. fayalites and magnetites. the formulae were normalized so that the sum of tetrahedral and octahedral cations $=4$. 3 and 3 respectively; for amphiboles the sum of $M_{1}, M_{2}$, $\mathrm{M}_{3}$ and tetrahedral cations was taken as 13 for $\mathrm{Fe}, \mathrm{Mn}$. $\mathrm{Mg}, \mathrm{Al}, \mathrm{Ti}, \mathrm{Si}$. This technique is critically dependent on careful elemental analyses, especially for $\mathrm{Si}$ and $\mathrm{Al}$, and assumes stoichiometric phases; however. errors as large as $50 \%$ in the estimated $\mathrm{Fe}^{3+}$ of the silicates will not significantly affect the calculations and conclusions which follow.

\section{ANALYTICAL RESULTS AND DISCUSSION}

The calculated phase relations for hedenbergiteandradite-fluorite-quartz-iron oxide in $f_{\mathrm{O}_{2}}-f_{\mathrm{F}_{2}}$ space 


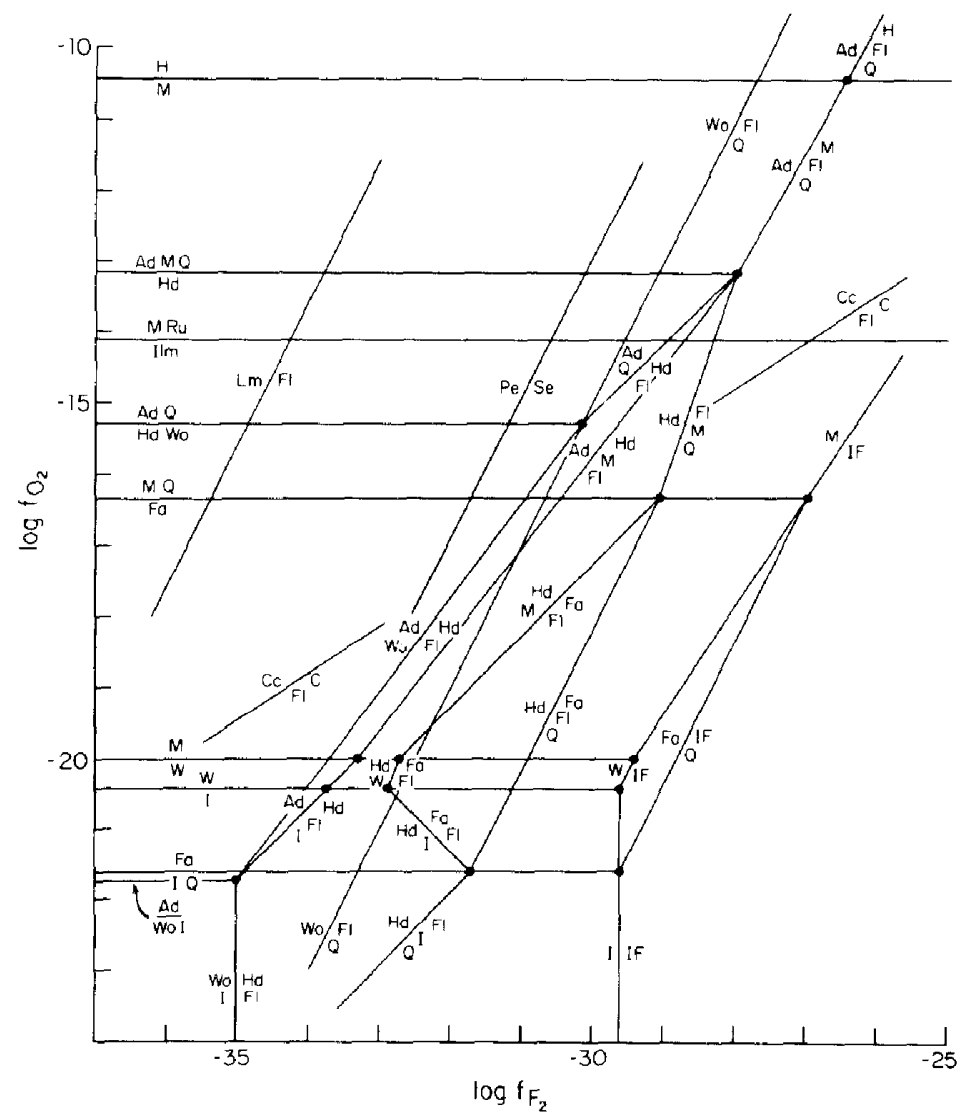

Fig. 2. $f_{\mathrm{O}_{2}}-f_{\mathrm{F}_{2}}$ diagram for selected silicate-oxide-fluoride reactions. Mineral abbreviations, free energy and volume data are given in Table 1 . Temperature and pressure are fixed at $T=1000 \mathrm{~K}$, $P=7 \mathrm{kbar}$

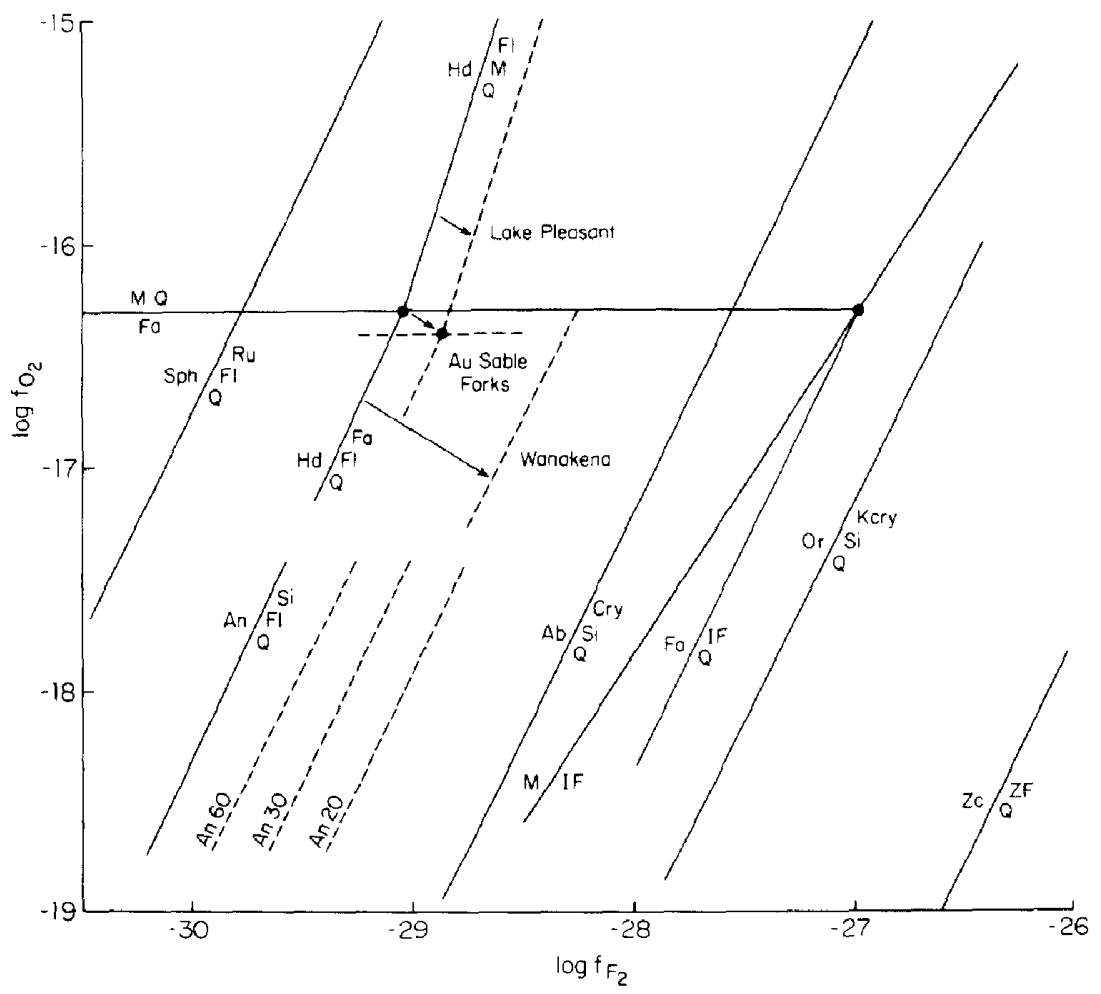

Fig. 3. $f_{\mathrm{O}}, f_{\mathrm{F}_{2}}$ diagram showing an enlargement of a portion of Fig. 2. Calculated shifts for the three Adirondack samples are illustrated. 
Table 2. Comparison of estimated $f_{\mathrm{F}_{2}}$ for the AFSQ and WFQ buffers at $f_{\mathrm{O}_{2}}$ fixed by NNO for $P_{s}=2 \mathrm{kbar}$

\begin{tabular}{lccc}
\hline Rcference & WFQ(NNO) & AFSQ(NNO) & \\
\hline Munoz and Eugster (1969) calc. & A=-logf $F_{2}$ & $B=-\operatorname{logf}_{F_{2}}$ & $A-B$ \\
Munoz and Ludington (1974) expti. & $(30.1$ & 27.1 & 3.0 \\
Calc. from Robie and Waldbaum (1968) & 30.0 & $(28.1)$ & 1.9 \\
Caic. from table 1 (this paper) & 30.6 & 28.8 & 1.2 \\
\hline
\end{tabular}

at constant $P-T(P=7 \mathrm{kbar}, T=1000 \mathrm{~K})$ are shown in Fig. 2. The $P-T$ were chosen so that the diagram would apply to wide areas of the Adirondacks. Temperatures of $700-800^{\circ} \mathrm{C}$ for the Adirondacks Highlands have been determined by BOHLEN and ESSENE (1977a) using magnetite-ilmenite and feldspar thermometry (BUDDINGTON and LINDSLEY, 1964; STORMER, 1975). Pressures in the Adirondacks can be estimated by sphalerite-pyrite-pyrrhotite barometry (BRown et al., 1978), by the occurrence of ferrosiliterich orthopyroxenes, by the assemblage fayalitequartz and by the ubiquitous presence of sillimanite. If impurities in the olivine-orthopyroxene-quartz system are considered (BOHLEN and ESSENE, 1977b), the sulfide, pyroxene and $\mathrm{Al}_{2} \mathrm{SiO}_{5}$ systems restrict Adirondack pressures to $6 \pm 1 \mathrm{kbar}$ in the Lowlands to $8 \pm 1 \mathrm{kbar}$ in the Highlands.

The topology (Fig. 2) shows that fluorite-bearing assemblages significantly restrict fluorine fugacities. The upper $f_{F_{2}}$ limit in terrestrial rocks is apparently represented by the fluoridation of iron oxide to iron fluoride since iron fluoride (a relatively soluble phase) is unknown as a mineral. Other reactions such as the fluoridation of zircon and rutile lie to the fluorinerich side of the iron fluoride curve (Fig. 3). These reactions presumably restrict maximum fluorine fuga-

Table 3. Analyses of coexisting amphibole, fayalite, ferrohedenbergite (with ilmenite, fluorite, quartz) from Wanakena, New York

\begin{tabular}{|c|c|c|c|}
\hline & $\begin{array}{c}\text { NF-4 } \\
\text { Amphibole }\end{array}$ & $\begin{array}{c}N F-4 \\
\text { Fayalite }\end{array}$ & $\begin{array}{l}\mathrm{NF}-4 \\
\text { Ferrohedenbergite }\end{array}$ \\
\hline $\begin{array}{l}\mathrm{SiO}_{2} \\
\mathrm{TiO}_{2} \\
\mathrm{Al}_{2} \mathrm{O}_{2} \\
\mathrm{FeO}^{*} \\
\mathrm{MnO} \\
\mathrm{MgO} \\
\mathrm{CaO} \\
\mathrm{Na}_{2} \mathrm{O} \\
\mathrm{K}_{2} \mathrm{O} \\
\mathrm{CI} \\
\mathrm{F} \\
\text { TOTAL } \\
0=\mathrm{Cl}, \mathrm{F} \\
\text { TOTAL } \\
\text { TOTAL } \star\end{array}$ & $\begin{array}{r}39.83 \\
1.74 \\
8.49 \\
32.06 \\
0.83 \\
0.79 \\
9.57 \\
1.56 \\
1.75 \\
0.62 \\
1.71 \\
98.95 \\
0.86 \\
98.09 \\
98.71\end{array}$ & $\begin{array}{r}29.44 \\
0.00 \\
0.00 \\
68.23 \\
1.58 \\
0.56 \\
0.04 \\
\text { nd } \\
\text { nd } \\
\text { nd } \\
\text { nd } \\
98.85 \\
0.00 \\
99.85 \\
99.88\end{array}$ & $\begin{array}{r}48.79 \\
0.24 \\
0.89 \\
30.57 \\
0.73 \\
1.08 \\
16.22 \\
1.19 \\
0.00 \\
\text { nd } \\
\text { nd } \\
99.71 \\
0.00 \\
99.71 \\
99.82\end{array}$ \\
\hline $\begin{array}{l}\mathrm{Si} \\
\mathrm{Al} \\
\mathrm{Al} \\
\mathrm{Ti} \\
\mathrm{Fe}^{\mathrm{i+}} \\
\mathrm{Mg} \\
\mathrm{Me}^{2+} \\
\mathrm{Mn} \\
\mathrm{Ca} \\
\mathrm{Na} \\
\mathrm{K} \\
\mathrm{F} \\
\mathrm{Cl} \\
\mathrm{OH}\end{array}$ & $\begin{array}{l}6.491 \\
1.509 \\
0.120 \\
0.213 \\
0.768 \\
0.192 \\
3.593 \\
0.115 \\
0.669 \\
0.492 \\
0.363 \\
0.878 \\
0.171 \\
0.951\end{array}$ & $\begin{array}{c}0.996 \\
-.- \\
\cdots \\
-.- \\
0.008 \\
0.028 \\
1.922 \\
0.045 \\
0.001 \\
-- \\
-- \\
-.- \\
--\end{array}$ & $\begin{array}{c}2.002 \\
0.000 \\
0.043 \\
0.007 \\
0.035 \\
0.066 \\
1.014 \\
0.025 \\
0.713 \\
0.094 \\
0.000 \\
-. . \\
-. .\end{array}$ \\
\hline
\end{tabular}

* Total iron as FeO.

** Total corrected for calculated ferric iron.
Table 4. Analyses of cocxisting fayalite, ferrohedenbergite, magnetite (with fluorite, quartz) from Au Sable, New York (AS) and coexisting ferrosalite. magnetite (with fluoritc, orthopyroxcnc, quartz) from Lake Pleasant. New York (LP)

\begin{tabular}{|c|c|c|c|c|c|}
\hline & $\begin{array}{l}\text { As } \\
\text { Faya- } \\
\text { lite }\end{array}$ & $\begin{array}{l}\text { As } \\
\text { Ferro- } \\
\text { heden- } \\
\text { bergite }\end{array}$ & $\begin{array}{c}\text { As } \\
\text { Magne- } \\
\text { tite }\end{array}$ & $\begin{array}{l}\text { LP } \\
\text { Ferro- } \\
\text { salite }\end{array}$ & $\begin{array}{c}\text { LP } \\
\text { Magne- } \\
\text { tite }\end{array}$ \\
\hline $\begin{array}{l}\mathrm{SiO}_{2} \\
\mathrm{TiO}_{2} \\
\mathrm{Al}_{2} \mathrm{O}_{3} \\
\mathrm{FeO}^{*} \\
\mathrm{MnO}^{*} \\
\mathrm{MgO} \\
\mathrm{CaO} \\
\mathrm{Na}_{2} \mathrm{O} \\
\mathrm{K}_{2} \mathrm{O}\end{array}$ & $\begin{array}{r}29.64 \\
0.00 \\
0.00 \\
67.45 \\
1.45 \\
1.09 \\
0.05 \\
\text { nd } \\
\text { nd }\end{array}$ & $\begin{array}{r}47.93 \\
0.79 \\
1.21 \\
29.76 \\
1.97 \\
0.73 \\
17.24 \\
0.78 \\
0.02\end{array}$ & $\begin{array}{r}0.00 \\
0.09 \\
0.46 \\
92.89 \\
0.00 \\
0.02 \\
\text { nd } \\
\text { nd } \\
\text { nd }\end{array}$ & $\begin{array}{r}48.60 \\
0.14 \\
1.23 \\
23.47 \\
0.53 \\
4.06 \\
20.40 \\
0.41 \\
0.00\end{array}$ & $\begin{array}{r}0.00 \\
0.26 \\
0.47 \\
97.87 \\
0.00 \\
0.00 \\
\text { nd } \\
\text { nd } \\
\text { nd }\end{array}$ \\
\hline $\begin{array}{l}\text { TOTAL } \\
\text { TOTAL ** }\end{array}$ & $\begin{array}{l}99.68 \\
99.68\end{array}$ & $\begin{array}{l}99.81 \\
99.95\end{array}$ & $\begin{array}{r}93.46 \\
100.24\end{array}$ & $\begin{array}{l}98.84 \\
98.95\end{array}$ & $\begin{array}{l}92.60 \\
99.23\end{array}$ \\
\hline $\begin{array}{l}\mathrm{Si} \\
\mathrm{Al} \\
\mathrm{A}] \\
\mathrm{Ti}^{-} \\
\mathrm{Fe}^{3+} \\
\mathrm{Mg} \\
\mathrm{Fe}^{2+} \\
\mathrm{Mn} \\
\mathrm{Ca} \\
\mathrm{Na} \\
\mathrm{K} \\
\mathrm{K}\end{array}$ & $\begin{array}{l}1.000 \\
0.000 \\
0.000 \\
0.000 \\
0.000 \\
0.055 \\
1.902 \\
0.041 \\
0.002 \\
0.000 \\
0.000 \\
0.000\end{array}$ & $\begin{array}{l}1.973 \\
0.027 \\
0.032 \\
0.006 \\
0.045 \\
0.045 \\
0.980 \\
0.069 \\
0.761 \\
0.062 \\
0.000 \\
0.000\end{array}$ & $\begin{array}{c}0.000 \\
0.021 \\
--- \\
0.002 \\
1.975 \\
0.001 \\
1.001 \\
0.000 \\
-.- \\
-.- \\
-.-\end{array}$ & $\begin{array}{l}1.965 \\
0.035 \\
0.023 \\
0.004 \\
0.004 \\
0.245 \\
0.790 \\
0.018 \\
0.884 \\
0.032 \\
0.000 \\
0.000\end{array}$ & $\begin{array}{c}0.000 \\
0.025 \\
\ldots .021 \\
0.021 \\
1.935 \\
0.000 \\
1.018 \\
0.000 \\
-\ldots \\
-. \\
\ldots-\end{array}$ \\
\hline
\end{tabular}

* Total iron as $\mathrm{FeO}$

** Total corrected for calculated ferric iron

cities in most crustal rocks. The writers have also calculated andradite reactions which arise from invariant points involving hedenbergite, so that the diagram might be more widely applicable to skarns and other rocks of the granulite facies. It is shown in Fig. 2 that andradite-bearing assemblages restrict the lower $f_{\mathrm{F}_{2}}$ limit of fluorite-hedenbergite stability. A number of typical skarn assemblages such as andradite-wollastonite-hedenbergite-fluorite and andradite-hedenbergite-magnetite-fluorite are univariant for the end-member compositions. Discovery of fluorite in iron-rich skarns containing garnet-clinopyroxene-wollastonite-quartz and garnet-clinopyroxenemagnetite-quartz described by HoLTZ and WILLDEN (1964), LeONARD and BUdDINGTON (1964) and BLRT (1971) would make these assemblages invariant, fixing $f_{\mathrm{O}_{2}}-f_{\mathrm{F}_{2}}$. Hence, one must be careful not to overlook even minor amounts of fluorite in Fe-rich rocks when evaluating $f_{\mathrm{F}}$. Figure 2 and similar relations at various other $P$ - $T$ conditions will be useful in estimating fluorine and oxygen fugacities in a number of skarn assemblages if adjustments in the equilibria are made for mineral impurities.

Although fluorites in Adirondack gneisses are probably igneous in origin, their stability in the subsequently metamorphosed charnockites, mangerites and granites is important since the fluorite-bearing assemblages buffered $f_{\mathrm{O}_{2}}$ and $f_{\mathrm{F}_{2}}$ during metamorphism. Most of the fluorite-bearing assemblages in granitic rocks are divariant (at constant $P-T$ ) and do not uniquely restrict fluorine fugacities. However, the fayalite-granite assemblages near Wanakena and Au 
Sable Forks, New York, tightly constrain fluorine and oxygen fugacities. The Wanakena assemblage of fayalite-ferrohedenbergite-amphibole-ilmenite-fluorite-quartz is univariant (at constant $P-T$ and for the endmember system). Oxygen fugacities can be approximated from a fayalite-magnetite $\left(\mathrm{Uv}_{29}\right)$ ilmenite $\left(\mathrm{Hm}_{6}\right)$-quartz assemblage found in the same rock body less than 0.5 miles away. Applying the Buddington-Lindsley oxygen barometer, this assemblage requires oxygen fugacities of $10^{-17}$ bar at $700^{\circ} \mathrm{C}$. One cannot assume the oxygen fugacity will be the same throughout the rock body, and indeed slight local variations in $f_{\mathrm{O}}$, probably account for the sporadic occurrence of magnetite in the Wanakena fayalite granite. Nevertheless, justification for using $10^{-17}$ as an approximate $f_{\mathrm{O}_{2}}$ is supported by the data of BOHLEN and EssENE (1977a) which indicates that a number of different orthogneisses throughout the Adirondacks have oxygen fugacities within $10^{ \pm 1}$ of the quartz-magnetite-fayalite buffer as determined by magnetite--ilmenite (BUDDINGTON and LINDSLEY, 1964). If oxygen fugacities in the Wanakena fayalite granite are $10^{-17 \pm 1}$ bar, then fluorine fugacities can be restricted to $10^{-28.6 \pm 0.3}$ bar when impurities in the fayalite and ferrohedenbergite are considered (Fig. 3).

The effect of additional components on the calculated equilibria can be corrected for by the equation:

$$
f_{\mathrm{O}_{2}} / f_{\mathrm{F}_{2}}=\left(f_{\mathrm{O},}^{\prime} / f_{\mathrm{F}_{2}}^{\prime}\right) \cdot \frac{a_{i}^{b} \cdot a_{j}^{c} \ldots}{a_{x}^{m} \cdot a_{y}^{n} \ldots}
$$

where $f_{\mathrm{O}_{2}}^{\prime}$ and $f_{\mathrm{F}_{2}}^{\prime}$ are the calculated fugacities for the end-member minerals at the $P-T$ of interest and where $a_{i}^{b} a_{j}^{c}$ are the activities of product phases $i$ and $j$ raised to their respective numerical reaction coefficients $(b, c \ldots)$. Similarly $a_{x}^{m}, a_{y}^{n}$ are the activities of the reactant phases $x, y$, etc.. raised to their numerical reactant coefficients $m, n$, etc. When the necessary activity data are not available, the substitution of mole fraction $X_{i}$ for $a_{i}$ allows calculation of an approximate shift of end-member reactions due to additional components.

The calculated equilibria in Fig. 3 show that fayalite-ferrohedenbergite-fluorite granites require relatively high $f_{\mathrm{F}_{2}}$ values, above the stability of most plagioclase compositions. Preliminary examination of other fayalite granites suggest the assemblage fayalite ferrohedenbergite fluorite quartz is common and deserves more attention. Rocks containing cryolitequartz at Ivigtut, Greenland and cryolite-topazquartz at Pikes Peak, Colorado (Hurlbut, 1971) may require similar or slightly higher fluorine fugacities than fayalite-hedenbergite-fluorite granites, although the phase relations have not yet been considered in detail.

Rocks not containing fluorite may well have formed under lower $f_{\mathbf{F}_{2}}$ conditions than those discussed in this paper. Rocks containing sphene (which is very common in the Adirondacks) appears to require at least an order of magnitude lower $f_{\mathrm{F}_{2}}$ at the same $f_{\mathrm{O}_{2}}$ compared to the assemblage $\mathrm{Hd}-\mathrm{Fl}$ - $-\mathrm{Fa}$ (Fig. 3). In fluorite-free rocks reactions involving $\mathrm{F} / \mathrm{OH}$ exchange between coexisting micas, amphiboles, mica-amphibole or mica/amphiboleapatite must then be sought to estimate $f_{\mathrm{F}_{2}}$. For these assemblages $f_{\mathrm{H}_{2} \mathrm{O}}$ and $f_{\mathrm{O}_{2}}$ will first need to be estimated before $f_{\mathrm{F}_{2}}$ and $f_{\mathrm{HF}}$ can be evaluated.

The Wanakena fayalite granite is special in that the assemblage fluorite-fayalite-ferrohedenbergiteamphibole is found as clots in a matrix of quartz and feldspar with minor amounts of ilmenite, zircon and apatite (see Fig. 1). There is textural evidence for the reaction:

$$
\begin{aligned}
& \mathrm{NaCa}_{2} \mathrm{Fe}_{5} \mathrm{AlSi}_{7} \mathrm{O}_{22} \mathrm{~F}_{2}= \\
& \text { ferrofluoredenite } \\
& \mathrm{CaF}_{2}+2 \mathrm{Fe}_{2} \mathrm{SiO}_{4}+\mathrm{CaFeSi}_{2} \mathrm{O}_{6}+\mathrm{NaAlSi}_{3} \mathrm{O}_{8} \\
& \text { fuorite fayalite hedenbergite albite }
\end{aligned}
$$

This reaction can be approximately balanced using analyzed mineral compositions (Table 3) if ilmenite, plagioclase, and a fluid (containing $\mathrm{H}_{2} \mathrm{O}, \mathrm{Cl}_{2}, \mathrm{~F}_{2}, \mathrm{O}_{2}$ ) are considered as additional phases. If the complex decomposition of ferrofluoredenite occurs in this rock. the reaction (for the non-end-member phases) must intersect the univariant reaction:

$$
\begin{aligned}
& 2 \text { hedenbergite }+2 \mathrm{~F}_{2} \\
& =\text { fayalite }+2 \text { fluorite }+3 \text { quartz }+\mathrm{O}_{2}
\end{aligned}
$$

at an invariant point in $f_{\mathrm{O}_{2}}-f_{\mathrm{F}_{2}}$ space (at constant $P$, $T, f_{\mathrm{Cl}_{2}}, f_{\mathrm{H}_{2} \mathrm{O}}$ ).

In the Au Sable Forks fayalite granite the assemblage fayalite-ferrohedenbergite-fluorite-magnetitequartz (Table 4 ) is invariant in $f_{\mathrm{O}_{2}}-f_{\mathrm{F}_{2}}$ space at constant $P-T$. For this rock, $f_{\mathrm{F}_{2}}$ and $f_{\mathrm{O}_{2}}$ are $10^{-28.9 \pm 0.3}$ and $10^{-16.4 \pm 0.2}$ bar respectively (Fig. 3). Elsewhere in the outcrop fayalite-magnetite-ilmenite-quartz fixes $f_{\mathrm{O}_{2}}-\mathrm{T}$ at $10^{-17}$ bar and $710^{\circ} \mathrm{C}$ (BOHLEN and ESSENE, 1977a). Within the same outcrop, another rock type contains the assemblage magnetiteilmenite-biotite-K-feldspar. This assemblage fixes $f_{\mathrm{O}_{2}}-f_{\mathrm{H}_{2} \mathrm{O}}$ and $T\left(725^{\circ} \mathrm{C}\right)$ using data from BLDDINGTON and LindSLEY (1964) and WONes (1972). This assemblage and other assemblages around the Adirondack Highlands restrict water fugacities to $<10^{3.3} \pm 0.2$ bar (BOHLEN and EsSENE, in prep.). There is a substantial uncertainty in $f_{\mathrm{H}_{2} \mathrm{O}}$ determination because of the problem of calculating the annite component in micas with significant amounts of impurities (halogens. Mn, Ti $\mathrm{Al}^{\mathrm{V}}, \mathrm{Fe}^{3+}$, interlayer and octahedral site deficiencies, etc.). If an annite component is calculated as $\mathrm{X}($ annite $)=\mathrm{Fe}^{2+} /\left(\mathrm{Fe}^{2+}+\mathrm{Mg}\right)$, the water fugacity for the $\mathrm{Au}$ Sable assemblage magnetite $\left(\mathrm{Uv}_{32}\right)$ ilmenite $\left(\mathrm{Hm}_{5}\right)$-biotite $\left(\mathrm{Ann}_{56}\right)$-perthite $\left(\mathrm{Or}_{67}\right)$ is $10^{3.3}$ However, this $f_{\mathrm{H}_{2} \mathrm{O}}$ value represents an upper limit as other schemes for calculating annite components from complicated biotite formulae (Wonss. 1972; CZAMANSKE and WONES, 1973) yield much lower annite mole fractions and hence lower water fugaci- 
ties. Indeed WONEs (1972) inferred water fugacities on the order of $10^{1}$ for orthogneisses in the NW Adirondacks. Nevertheless for the Au Sable outcrop an upper limit on $f_{\mathrm{H}_{2} \mathrm{O}}$ will allow calculation of limiting values for $f_{\mathrm{HF}}$ and $f_{\mathrm{H}_{2}}$, assuming no large gradients in $f_{\mathrm{H}_{2} \mathrm{O}}$ in the Au Sable outcrop and assuming ideal mixing of gases. The calculated results are $f_{\mathrm{H}_{2}} \leq 10^{1.4}$ har and $f_{\mathrm{HF}}<10^{0.3}$ bar for $727^{\circ} \mathrm{C}, f_{\mathrm{F}_{2}} \simeq 10^{-28.9}$ bar, $f_{\mathrm{O}_{2}} \simeq 10^{-16.4}$ bar and $f_{\mathrm{H}_{2} \mathrm{O}} \leq 10^{3.3}$ bar. Taking into account the errors in our analysis, it can be seen that $\mathrm{H}_{2}$ and $\mathrm{HF}$ fugacities are on the order of $10^{1}$. If the limiting $f_{\mathrm{H}_{2} \mathrm{O}}$ value of $10^{3.3}$ is too high, the magnitude of $\mathrm{HF}$ and $\mathrm{H}_{2}$ decrease somewhat. For $f_{\mathrm{H}_{2} \mathrm{O}}=10^{2}$ bar at $f_{\mathrm{O}_{2}} \simeq 10^{-16.4}$ bar and $f_{\mathrm{F}_{2}} \simeq 10^{-28.9}$ bar, $f_{\mathrm{H}_{2}} \simeq 10^{0.2}$ bar and $f_{\mathrm{HF}} \simeq 10^{0.1}$ bar.

Of course errors in the calculated phase diagram will generate uncertainty in the esimated $f_{\mathrm{O}_{2}}$ and $f_{\mathrm{F}_{2}}$. However, for the fayalite-magnetite-quartz bearing assemblages, the errors in $f_{\mathrm{O}_{2}}$ will be small since the inferred $f_{\mathrm{O}_{2}}$, has been confirmed by magnetite-ilmenite analysis in nearby rocks (BOHLEN and ESSENE, 1977a). Uncertainties in $f_{\mathrm{F}_{2}}$ are generated by errors in $\Delta G_{T}^{0}$ for reactants and products of a given reaction. The $\Delta G_{T}^{0}$ for hedenbergite probably has a relatively large error as it was calculated simultaneously with andradite from two experimental curves. A change of \pm 3 $\mathrm{kcal}$ in $\Delta G_{T}^{0}(\mathrm{Hd})$ will shift the calculated $f_{\mathrm{F}_{2}}$ in the hedenbergite reactions by about $10^{ \pm 0.5}$. Errors of $1-2$ kcal must still be anticipated for many of the other phases in Table 1, producing errors of approximately $10^{ \pm 0.3}$ in the calculated curves.

The estimated $f_{\mathrm{F}_{2}}$ and $f_{\mathrm{O}_{2}}$ in the fayalite granites are generally consistent with the calculated stabilities of other minerals such as zircon, ilmenite, albite, $\mathrm{K}$-feldspar and sphene. The writers did not find the assemblage, ferrohedenbergite-fayalite-fluoritequartz-sphene in rocks from Wanakena consistent with sphene's instability as calculated in Fig. 3. However, LEONARD and BUDDINGTON (1964) do report sphene in the Wanakena fayalite-ferrohedenbergite granite, posing a problem if it is in equilibrium with fayalite-ferrohedenbergite-quartz-fluorite. This descrves further study particularly in analyzing the sphene to see if additional components can extend the sphene stability field. The relatively large error in the $\Delta G_{T}^{0}$ of sphene (HUNT and KERRICK, 1977) may also explain the inconsistency. The stability of albite may be contracted by a more stable reaction involving topaz instead of sillimanite, but no $\Delta G_{T}^{0}$ data are available for the topaz calculation.* The calculations suggest that cryolite may be stable instead of albite in some fayalite granites, and it should be considered as a possible phase in such rocks. The effect of solid solution on plagioclase stability was calculated using ORVILLE's (1972) activity coefficients for albite and

\footnotetext{
* The AFSQ buffer itself may become metastable with respect to topaz; carefully reversed experiments or accurate thermochemical data for topaz are necessary to evaluate this possibility.
}

anorthite components. It can be seen that the hedenbergite reactions are close to the upper stability of intermediate plagioclases, and plagioclase-bearing rocks in the Adirondacks must have equilibrated at lower $f_{\mathrm{F}_{2}}$ for comparable $f_{\mathrm{O}_{2}}$ (assuming the same $P-T$ ).

\section{ADIRONDACK METAMORPHIC FLUIDS}

Even though $f_{\mathrm{O}_{2}}$ and $f_{\mathrm{F}_{2}}$ directly govern the reactions considered in Figs. 2 and 3 and other reactions generating fluorite-bearing assemblages, their values are insignificant compared to $f_{\mathrm{H}_{2}}, f_{\mathrm{HF}}$ and $f_{\mathrm{H}_{2} \mathrm{O}}$. Even $f_{\mathrm{II}_{2}}$ and $f_{\mathrm{IIT}}$ have low values: if a fluid phase equilibrated with these granites, the mole fraction of $\mathrm{H}_{2}$ and $\mathrm{HF}$ would each be less than 0.001 . Preliminary data on $f_{\mathrm{H}_{2} \mathrm{O}}$ indicate that water pressures in the Adirondacks are substantially less than solid pressure. This is not altogether surprising since substantial melting would be required for many charnockites and granites containing microcline-albite-quartz at Adirondack $P-T$ if water pressures approximated solid pressures. Since there is little evidence of extensive partial melting in the Adirondack Highlands (such as migmatites or restites), it must be concluded that water pressures are much less than solid pressures for granulite facies metamorphism in the Adirondacks. The writers suspect that this may be a general condition of granulite facies metamorphism elsewhere, and it should not be assumed that $P_{\mathrm{H}_{2} \mathrm{O}} \approx P_{\mathrm{s}}$ in high-grade metamorphic rocks. As might be expected, it appears that $\mathrm{O}_{2}, \mathrm{H}_{2}, \mathrm{~F}_{2}$ and $\mathrm{HF}$ do not play a significant role in maintaining high fluid pressures in the $\Lambda$ dirondacks. We conclude that $P_{\mathrm{H}_{2} \mathrm{O}}$ is $\leq 0.25 P_{\text {solid }}$ and that $P_{\text {fluid }} \ll P_{\text {solid }}$ unless other gas species such as $\mathrm{CO}_{2}$ or $\mathrm{Ar}$ are present in quantities sufficient to maintain high fluid pressures.

Acknowledgements-The writers are thankful for the support of National Science Foundation Grant No. 014573 to EJE. Geological Society of America Grant No. 2003-75 to SRB and the Turner Fund of The University of Michigan. The electron microprobe facilities at The University of Michigan are supervised by Professor WILBUR C. BIGELow of the Department of Metallurgy and Material Science whose cooperation made this study possible. Several members of this staff, particularly L. F. ALLARD, P. J. Hollingsworth and A. J. Mardingly, gave valuable assistance during data collection. The writers wish to thank Dr. D. R. Peacor and Dr. W. C. Kelly of the Department of Geology and Mineralogy, The University of Michigan, for the reviews of the manuscript. Dr. D. R. WONES and Dr. L. G. Liou are also thanked for their manuscript reviews. Mr. Derwin Bell drafted the line drawings which appear in this paper.

\section{REFERENCES}

American Society for Testing Materials, X-ray Powder Data File (1960 and later).

Bohlen S. R. and EsSEne E. J. (1977a) Feldspar and oxide thermometry of granulites in the Adirondack Highlands. Contrib. Mineral. Petrol. 62, 153-169.

BOHLEN S. R. and EsseNE E. J. (1977b) Errors in applying olivine-quartz-orthopyroxene barometry. Trans. Am Geophys. Union 58, 1242. 
Brown P. E., Esstent E. J. and Kelly W. C. (1977) Sphalerite geobarometry in the Balmat-Edwards district. New York. Am. Mineralogist 63, 250-257.

Budisingion A. F. and Llunard B. F. (1962) Regional geology of the St. Lawrence County magnetite district. Northwest Adirondacks. New York. U.S. Geol. Surv. Prof. Puper 376, 1-145.

BUidington A. F. and LindsLey D. H. (1964) Irontitanium oxide minerals and their synthetic equivalents. J. Petrol. 5, 310-357.

Burt D. M. (197I) The facies of some Ca-Fe-Si skarns in Japan. Carnegie Inst. Wash. Yearh. 70, 185197.

Burr D. M. (1972) The influence of fluorine on the facies of $\mathrm{Ca}-\mathrm{Fe}-\mathrm{Si}$ skarns. Carnegie Inst. Wash. Yearb. 71, 443459.

Clark S. P.. JR. (1966) Handbook of Physical constants. Geol. Soc. Am. Mem. 97.

CODATA (1976) Recommended values for thermodynamics. J. Che'm. Thermodyn. 9. 1-6.

Czamanske G. K. and Wones D. R. (1973) Oxidation during inlagmatic differentiation, Finnmarka Complex. Oslo Area, Norway: Part 2, the mafic silicates. J. Petrol. 14, $349-380$

Hrmingway B. S. and Robie R. A. (1977) Enthalpies of formation of low albite $\left(\mathrm{NaAlSi}_{3} \mathrm{O}_{8}\right)$ gibbsite $\left[\mathrm{Al}(\mathrm{OH})_{3}\right]$ and $\mathrm{NaAlO}_{2}$; revised values for $\Delta H_{f .298}$ and $\Delta G 29$ of some aluminous minerals. U.S. Geol. Surt. J. Res. 5, 413-429.

Holtz P. E. and WiLlden R. (1964) Geology and mineral deposits of the Osgood Mountains quadrangle. Humbolt County, Nevada. U.S. Geol. Sure. Prof. Paper 431, 1-128.

HUNT J. A. and KerRICK D. M. (1977) The stability of sphene: expcrimental redetermination and geological implications. Geochim. Cosmochim. Acta 41, 279-288.

Hurlbut C. S. (1971) Dana's Manual of Mineralogy.

JANAF Thermochemical Tables (1971) Tables of thermochemical data, compiled by the Dow Chemical Company. Thermal Laboratory, Midland, MI. 2nd Edit.

JANAF Thermochemical Tables (1974 suppl.) CHASE M. W. Curnutt J. L.. Prophet H. McDonald R. A and Syverud A. N. J. Phis. Chem. Ref. Data 3, 311-480

JANAF Thermochemical Tables (1975 suppl.) CHASE M. W., Curnutt J. L.. Hu A. T.. Prophet H., Syverud A. N. and Walker L. C. J. Phis. Chem. Ref. Data 4. 1175 .

Kemp J. F. and Alling H. L. (1925) Geology of the Au Sable Quadrangle. Bull. New York Mus. 261, 1-98.

Kurchakova L. D. and Averisyan E. I. (1974) Stability and properties of synthetic hedenbergite. Geochem. Internat. 3, 338-346.
Leonard B. F. and Buddington A. F. (1964) Ore deposits of the St. Lawrence Co. Magnetite district, N. W. Adirondacks. NY. U.S. Geol. Surv. Prof. Paper 377, 1-259.

LIOU: J. G. (1974) Stability relations of andradite-quartz in the system $\mathrm{Ca}-\mathrm{Fe}-\mathrm{Si}-\mathrm{O}-\mathrm{H}$. Am. Mineralogist $\mathbf{5 9}$, 1016-1025.

Lindsley D. H., MUNOZ J. L. and Finger L. (1968) Unit cell parameters of clinopyroxenes along the join hedenbergite-ferrosillite. Carnegie Inst. Wash. Yearb. 67, 91-92.

Munoz J. L. and Eugster H. P. (1969) Experimental control of fluorine reactions in hydrothermal systems. Am. Mineralogist 54, 943-959.

Munoz J. L. and Lubington S. D. (1974) Fluoridehydroxyl exchange in biotite. Am. J. Sci. 274, 396-413.

Navrotsky A. and CoONs W. E. (1976) Thermochemistry of some pyroxenes and related compounds. Geochim. Cosmochim. Acta 40, 1281-1288.

Nordstrom D. K. and Jenne E. A. (1977) Fluorite solubility equilibria in selected geothermal waters. Geochim. Cosmochin. Acta 41, 175-188.

Orville P. M. (1972) Plagioclase cation exchange equilibria with aqueous chloride solution: Results at $700^{\circ} \mathrm{C}$ and 2000 bar in the presence of quartz. Am. J. Sci. 272, $234-272$.

Robie R. A.. Bethke P. M. and Beardsley K. M. (1967) Selected X-ray crystallographic data, molar volumes and densities of minerals and related substances. Bull. U.S Geol. Surt. 1248, 1-87.

Robie R. A. and Waldbaum D. R. (1968) Thermodynamic properties of minerals and related substances at $298.15 \mathrm{~K}\left(25.0^{\circ} \mathrm{C}\right.$ and one atm $(1.013$ bar) pressure and at higher temperatures. Bull. U.S. Geol. Surt. 1259, 1-253.

Rucklidge J. C. and Gasparrini E. L. (1969) Specifications of a complete program for processing electron microprobe data: EMPADR VII. Department of Geology, University of Toronto, Unpubl. circular.

SCHAEFER S. C. (1975) Free energies of formation of ferrous and ferric fluoride by EMF measurements. U.S. Bur. Mines. Rept. Invest. 8096, 114.

Stavely L. A. K. and Linforo R. G. (1969) The heat capacity and entropy of calcite and aragonite and their interpretation. J. Chem. Thermodyn. 1, 111

StORMER J. C.. JR. (1975) A practical two-feldspar thermometer. Am. Mineralogist 60, 667-674.

Stormer J. C.. Jr. and Carmichael I. S. E. (1970) Villiaumite and the occurrence of fluoride minerals in igneous rocks. Am. Mineralogist 55. 126-134.

WONES D. R. (1972) Stability of biotite- $\Lambda$ reply. Am. Mineralogist 57. 316-317. 